\title{
Modulation of apoptosis in human hepatocellular carcinoma (HepG2 cells) by a standardized herbal decoction of Nigella sativa seeds, Hemidesmus indicus roots and Smilax glabra rhizomes with anti- hepatocarcinogenic effects
}

\author{
Sameera R Samarakoon ${ }^{1 *}$, Ira Thabrew ${ }^{1}$, Prasanna B Galhena ${ }^{2}$ and Kamani H Tennekoon ${ }^{1}$
}

\begin{abstract}
Background: A standardized poly-herbal decoction of Nigella sativa seeds, Hemidesmus indicus roots and Smilax glabra rhizomes used traditionally in Sri Lanka for cancer therapy has been demonstrated previously, to have antihepatocarcinogenic potential. Cytotoxicity, antioxidant activity, anti-inflammatory activity, and up regulation of p53 and p21 activities are considered to be some of the possible mechanisms through which the above decoction may mediate its anti-hepatocarcinogenic action. The main aim of the present study was to determine whether apoptosis is also a major mechanism by which the decoction mediates its anti-hepatocarcinogenic action.

Methods: Evaluation of apoptosis in HepG2 cells was carried out by (a) microscopic observations of cell morphology, (b) DNA fragmentation analysis, (c) activities of caspase 3 and 9, as well as by (d) analysis of the expression of pro-apoptotic (Bax) and anti-apoptotic ( $\mathrm{BCl}-2$ ) proteins associated with cell death.

Results: The results demonstrated that in HepG2 cells, the decoction can induce (a) DNA fragmentation and (b) characteristic morphological changes associated with apoptosis (nuclear condensation, membrane blebbing, nuclear fragmentation and apoptotic bodies). The decoction could also, in a time and dose dependent manner, up regulate the expression of the pro-apoptotic gene Bax and down regulate expression of anti-apoptotic BCl-2 gene (as evident from RT-PCR analysis, immunohistochemistry and western blotting). Further, the decoction significantly $(p<.001)$ enhanced the activities of caspase-3 and caspase-9 in a time and dose dependent manner.
\end{abstract}

Conclusions: Overall findings provide confirmatory evidence to demonstrate that the decoction may mediate its reported anti-hepatocarcinogenic effect, at least in part, through modulation of apoptosis.

\section{Background}

A decoction prepared from a mixture of Nigella sativa seeds, Hemidesmus indicus roots and Smilax glabra rhizomes has traditionally been used for many years by a particular family of Ayurveda physicians in Sri Lanka [1] for the treatment of cancer patients. Findings of recent in vivo investigations carried out by Iddamaldeniya et al., (2003 and 2006) indicate that this poly-herbal decoction

\footnotetext{
* Correspondence: sam@ibmbb.cmb.ac.lk

'Institute of Biochemistry, Molecular Biology and Biotechnology, University of Colombo, 90, Cumarathunga Munidasa Mawatha, Colombo 3, Sri Lanka Full list of author information is available at the end of the article
}

has the potential to significantly inhibit chemically induced hepatocarcinogenesis $[1,2]$. The decoction has been standardized considering its High Performance Liquid Chromatography (HPLC) profile and physicochemical parameters according to WHO guidelines [3]. Further in vivo and in vitro investigations have demonstrated that cytotoxicity, $[3,4]$ antioxidant activity, antiinflammatory activity [5] and up regulation of p53 and p21 activities [6] are some of the possible mechanisms through which the above decoction may mediate its antihepatocarcinogenic action. 
Apoptosis or programmed cell death plays a crucial role in maintaining cellular homeostasis between cell division and cell death $[7,8]$. An imbalance between cell proliferation and apoptotic cell death will result in serious diseases such as cancer [9]. Cell death mediated by apoptosis results in a series of morphological changes such as nuclear condensation, nuclear fragmentation, and cell surface blebbing, which leads to the formation of membrane bound vesicles (apoptotic bodies) being subsequently phagocytised by macrophages [10]. Apoptosis is regarded as the most preferred way to manage cancer as this process does not affect neighbouring cells like in necrosis. Apoptosis can occur through a death receptor (extrinsic) pathway or a mitochondrial (intrinsic) pathway $[11,12]$. Both pathways will result in the activation of caspases, a family of enzymes that act as death effector molecules in various forms of cell death [13]. Apoptosis has been demonstrated to be a major mechanism employed by many natural agents $[14,15]$ to mediate anticancer effects.

Hepatocellular carcinoma (HCC) is one of the commonest malignant diseases of the world, and the most frequent primary liver cancer, with continuously increasing incidence over the past decade [16]. Since the decoction comprised of Nigella sativa seeds, Hemidesmus indicus roots and Smilax glabra rhizomes has been demonstrated experimentally to possess anti-hepatocarcinogenic properties $[1,2]$, for further development of this decoction for the treatment of human $\mathrm{HCC}$, it is important to investigate whether apoptosis is also a major mechanism by which it can mediate anticarcinogenic effects. Results of a preliminary flow cytometric analysis carried out recently by Thabrew et al., (2005) with HepG2 cells, indicated that the above decoction may have the potential to induce apoptosis [4]. Therefore the present study was carried out with the aim of obtaining further evidence to confirm that apoptosis is indeed a major mechanism through which the test decoction mediates its anti-hepatocarcinogenic effects. In the present study, evaluation of apoptosis in HepG2 cells was carried out by (a) microscopic observations of cell morphology, (b) DNA fragmentation analysis, (c) activities of caspase 3 and 9, as well as by (d) analysis of the expression of pro-apoptotic (Bax) and anti-apoptotic (Bcl-2) proteins associated with cell death.

\section{Methods}

Materials and methods

HepG2 cells were purchased from ECACC, Salisbury, UK. Dulbecco's Modified Eagle Medium (DMEM), and TRIzol reagent were purchased from Invitrogen, Life Technologies; U.S.A. Fetal bovine serum (FBS), streptomycin/penicillin, dimethyl sulfoxide (DMSO), agarose, Bradford's reagent and trypsin/EDTA and all other chemicals were purchased from Sigma Aldrich (Gillingham, Dorset, UK).
M-MLV reverse transcriptase system (A3500), and GoTaq DNA polymerase, were purchased from Promega Cooperation, Madisons, U.S.A. PCR primers were purchased from Integrated DNA Technologies (IDT) U.S.A. Primary and secondary antibodies, $\mathrm{ABC}$ staining kit and western blotting luminol reagent were purchased from Santa Cruz Biotechnology (Santa Cruz, CA). Caspase-3 and caspase-9 colorimetric kit was purchased from GenScript USA.

\section{Collection of plant material}

Plant material for the preparation of extracts and their authentication has been previously reported (Samarakoon et al., 2010). Plant material was purchased from a reputed vendor of herbal material used by traditional medical practitioners in Sri Lanka (D. J. Fernando Pvt Ltd, Gabose lane, Colombo 13). Voucher specimens of $N$. sativa seeds, $H$. indicus roots, and S.glabra rhizome (Voucher specimen nos.UOC/IBMBB/2009/01, UOC/IBMBB/2009/02 and $\mathrm{UOC} / \mathrm{IBMBB} / 2009 / 03)$, have been deposited at the Institute of Biochemistry, Molecular Biology \& Biotechnology, University of Colombo, Sri Lanka.

\section{Preparation of plant decoction}

The plant decoction was prepared as described previously (Samarakoon et al., 2010). Sixty grams (60 g) of plant material (composed of a mixture of $20 \mathrm{~g}$ each of $N$. sativa seeds, $H$. indicus roots and S. glabra rhizomes) were ground and boiled gently with $1.6 \mathrm{~L}$ distilled water for approximately $3 \mathrm{~h}$ to reduce the volume to $200 \mathrm{ml}$. The extract was then filtered through a layer of muslin, filtrate centrifuged at $3000 \mathrm{~g}$ for $15 \mathrm{~min}$ to remove any debris, and the supernatant freeze dried and stored at $-20^{\circ} \mathrm{C}$ until required. When required for experimental purposes, the freeze dried extract was reconstituted with the appropriate volume of distilled water containing 1\% DMSO.

\section{Cell culture}

HepG2 cells were grown in monolayer cultures in Dulbecco's Modified Eagle Medium (DMEM) supplemented with $10 \%$ fetal bovine serum, and $50 \mathrm{IU} / \mathrm{ml}$ penicillin and $50 \mu \mathrm{g} / \mathrm{ml}$ streptomycin. Cells were maintained at $37^{\circ} \mathrm{C}$ in 95\% air $/ 5 \% \mathrm{CO}_{2}$ atmosphere, with $95 \%$ humidity.

\section{Evaluation of HepG2 cell viability by MTT assay}

The viability of HepG2 cells $\left(2 \times 10^{5}\right.$ cells $\left./ \mathrm{ml}\right)$ incubated with the decoction for $24 \mathrm{~h}$ with different doses of the decoction were evaluated by the MTT (3-(4,5-Dimethylthiazol-2-yl)-2,5-diphenyltetrazolium bromide) assay as described previously [3].

\section{Effects of the decoction on viability of peripheral blood mononuclear cells}

The peripheral blood mononuclear cells collected from blood of healthy volunteers was used to evaluate effects 
of the decoction on normal (non-cancerous) human cells. Mononuclear cells were isolated by separation in Histopaque 1077 (Sigma). Diluted blood with Hank's Buffered Salt Solution (HBSS) was carefully layered onto Histopaque 1077 and centrifuged at $1000 \mathrm{rpm}$ for $10 \mathrm{~min}$. After centrifugation the opaque interface containing mononuclear cells were collected and washed with phosphate buffered saline (PBS). After isolation, cells in RPMI medium with $50 \mathrm{U} / \mathrm{ml}$ penicillin, $50 \mu \mathrm{g} / \mathrm{ml}$ streptomycin and $10 \%$ fetal bovine serum (Sigma) were seeded at a cell density of $2 \times 10^{5}$ cells $/ \mathrm{ml}$ in 24 well plates. Cells were maintained at $37^{\circ} \mathrm{C}$ in $95 \%$ air $/ 5 \% \mathrm{CO}_{2}$ atmosphere, with $95 \%$ humidity. Cultures were exposed only to medium containing 1\% DMSO (controls) or medium containing different concentrations of decoction dissolved in 1\% DMSO $(600 \mu \mathrm{g} / \mathrm{ml}-2400 \mu \mathrm{g} / \mathrm{ml})$, and incubated for $24 \mathrm{~h}$. At the end of this incubation period, to determine percentage of viable cells, the above cells were collected by centrifugation at $150 \mathrm{rpm}$ for $10 \mathrm{~min}$ and resuspended in $0.5 \mathrm{ml}$ of RPMI medium. Cells $(100 \mu \mathrm{l})$ were then mixed with $1: 1$ dilution of $(100 \mu \mathrm{l}) 0.4 \%$ trypan blue solution. Cell were counted using hemocytometer.

Isolation of total RNA and RT-PCR analysis of bax and bcl2 genes in HepG2 cells

HepG2 cells cultured for $24 \mathrm{~h}$ were incubated for 12,24 and $48 \mathrm{~h}$ respectively, with fresh medium containing different concentrations of the decoction (test cells) or 1\% DMSO (control cells). The concentrations of decoction used were $75,150,300,600$, and $1200 \mu \mathrm{g} / \mathrm{ml}$, and triplicate cell cultures were exposed to each concentration. Treated and control cell cultures were incubated for a further 12 , 24 or $48 \mathrm{~h}$. At the end of the incubation period cells were harvested and used for total RNA extraction for reverse transcription PCR (RT- PCR).

Total RNA was isolated from the HepG2 cells, using TRIzol reagent according to the manufacturer's specifications. Total RNA concentration in the final elutes was determined by using a spectrophotometer (UV-1700, pharmasprc, SHIMADZU, Japan). Each sample of isolated RNA was reverse transcribed by M-MLV reverse transcriptase system.

Each PCR was carried out in a master mix containing $1 X$ Green Go Taq Flexi Buffer, $2 \mathrm{mM} \mathrm{MgCl}_{2}, 10 \mathrm{mM}$ dNTPs and 1.25 U GoTaq DNA polymerase (Promega Inc. US) with $0.2 \mathrm{mM}$ of respective forward and reverse primers in $50 \mu \mathrm{l}$ reaction mix. The PCR amplification was carried out in a Mastercycler (Eppendrof, Hamburg, Germany). GAPDH (glyceraldehydes 3-phosphate dehydrogenase) amplification was performed as an internal control. PCR conditions for GAPDH were 30 cycles at $94^{\circ} \mathrm{C}$ for $30 \mathrm{sec}$, at $54^{\circ} \mathrm{C}$ for $30 \mathrm{sec}$ at $72^{\circ} \mathrm{C}$ for $1 \mathrm{~min}$. PCR conditions for $\mathrm{Bax}$ were $35 \mathrm{cycles}$ at $94^{\circ} \mathrm{C}$ for $1.5 \mathrm{~min}$, at $55^{\circ} \mathrm{C}$ for $30 \mathrm{sec}$, at $72^{\circ} \mathrm{C}$ for $1 \mathrm{~min}$. PCR conditions for
$\mathrm{Bcl}-2$ were 30 cycles at $94^{\circ} \mathrm{C}$ for $1.5 \mathrm{~min}$, at $56^{\circ} \mathrm{C}$ for $30 \mathrm{sec}$ at $72^{\circ} \mathrm{C}$ for $1 \mathrm{~min}$. The primers used for RT-PCR are shown in Table 1. Amplified PCR products were subjected to electrophoresis at $40 \mathrm{~V}$ through $2 \%$ agarose gel for 60 min. A 100 bp DNA ladder marker was used as a molecular marker. Gels were stained with $0.5 \mathrm{mg} / \mathrm{ml}$ ethidium bromide in TAE (Tris-acetate-EDTA) buffer. The gel bands were examined by using a Gel Doc imaging system and the intensity of each band was measured by using BIO RAD quantity one soft ware. Size of the amplified PCR products were $150 \mathrm{bp}$ for Bax, $129 \mathrm{bp}$ for $\mathrm{Bcl}-2$, and 226 bp for GAPDH.

\section{Immunohistochemistry}

HepG2 cells harvested by trypsinization, and $2 \times 10^{5}$ cells $/ \mathrm{ml}$ were plated on sterile coverslips placed in wells of a 24 well cell culture plate. The cells (on coverslips) were initially maintained in DMEM medium $(1 \mathrm{ml} /$ coverslip) for $24 \mathrm{~h}$ at $37^{\circ} \mathrm{C}$ in $95 \%$ air $/ 5 \% \mathrm{CO}_{2}$ atmosphere, with $95 \%$ humidity. Cultures were then treated with the standardized decoction $(600 \mu \mathrm{g} / \mathrm{ml}$ or $1200 \mu \mathrm{g} / \mathrm{ml})$ and incubated for $24 \mathrm{~h}$. Cells were then washed with phosphate buffer saline (PBS), fixed with cold 1:1 acetone: methanol for 15 minutes and then air dried. The coverslips with HepG2 cells were quenched with $1 \%$ BSA in $0.05 \mathrm{M}$ Tris $/ \mathrm{HCl}$ (pH 7.6) for $30 \mathrm{~min}$, and then incubated for $60 \mathrm{~min}$ at $37^{\circ} \mathrm{C}$ with anti-Bax and anti-BCL-2 rabbit polyclonal antibodies, diluted 1: 200. After washing with PBS (two times), the cells were incubated for $60 \mathrm{~min}$ with goat anti-rabbit IgG-HRP (diluted 1: 1000), washed again with PBS (two times) and visualized with ABC staining kit. Cells were counterstained with hematoxylin and examined under a light microscope.

\section{Western blot analysis}

For in vitro evaluation of Bax and Bcl-2 proteins in HepG2 cells by western blot analysis, cells were harvested after 12 , 24 and $48 \mathrm{~h}$ incubation with the decoction and centrifuged at $1000 \mathrm{~g}$ for $10 \mathrm{~min}$ at $4^{\circ} \mathrm{C}$. The pelleted cells were solubilized for $15 \mathrm{~min}$ at $4^{\circ} \mathrm{C}$ in lysis buffer [50 mM Tris- $\mathrm{HCl}$ pH 7.4, 150 mM NaCl, 1 mM EDTA, 1\% Nonidet P-40, $0.25 \%$ Na-deoxycholate, $1 \mathrm{mM}$ PMSF (phenylmethylsulfonyl fluoride) and proteinase inhibitor cocktail]. Lysates were centrifuged at $12,000 \mathrm{~g}$ for $15 \mathrm{~min}$ at $4^{\circ} \mathrm{C}$ to remove

\section{Table 1 Primer sequences used for RT PCR}

\begin{tabular}{ll}
\hline Name of Primer & Primer sequence \\
\hline Bax : forward primer & 5'-GGACGAACTGGACAGTAACATGG-3' \\
Bax : reverse primer & 5'-GCAAAGTAGAAAAGGGCGACAAC-3' \\
BCl-2: forward primer & 5'-ATCGCCCTGTGGATGACTGAG-3' \\
BCl-2: reverse primer & 5'- CAGCCAGGAGAAATCAAACAGAGG-3' \\
GAPDH: forward primer & 5'-GAAGGTGAAGGTCGGAGTC-3' \\
GAPDH: reverse primer & 5'-GAAGATGGTGATGGGATTC-3' \\
\hline
\end{tabular}


insoluble material. The supernatant was collected and protein concentration was determined using the Bradford's reagent. For Western blot analysis, samples (40 $\mu$ g each) were separated by electrophoresis on $10 \%$ SDS-polyacrylamide gels and transferred onto nitrocellulose membranes. The nitrocellulose membranes onto which proteins were transferred were pre-blocked with $5 \%$ non fat dry milk in PBS for $30 \mathrm{~min}$ and then incubated for $16 \mathrm{~h}$ at $4^{\circ} \mathrm{C}$ with specific primary antibodies. After three washes of $10 \mathrm{~min}$ each with $1 \times$ TBST (50 mM Tris- $\mathrm{HCl}, \mathrm{pH} 7.4,150 \mathrm{mM}$ $\mathrm{NaCl}, 1 \%$ Tween 20), each membrane was incubated with the secondary antibody for $30 \mathrm{~min}$ at room temperature. The membrane was then washed three times with TBST (10 $\mathrm{min} /$ wash) and bands visualized using western blotting luminol reagent system. Bands were normalized using $\beta$ actin antibody.

\section{Detection of morphological changes related to apoptosis by light microscopy}

HepG2 cells $\left(2 \times 10^{5}\right.$ cells $\left./ \mathrm{ml}\right)$ cultured in 24 well cell culture plates were exposed to different concentrations $(0-1800 \mu \mathrm{g} / \mathrm{ml})$ of the decoction (test cells) or $1 \%$ DMSO (control cells) respectively for further $24 \mathrm{~h}$. Morphological changes of the cells were then observed under a inverted light microscope (Olympus CKX41SF, Japan).

\section{Detection of morphological changes related to apoptosis by} fluorescent microscopy

HepG2 cells were seeded at a final concentration of $2 \times$ $10^{5}$ cells $/ \mathrm{ml}$ in 6 -well culture plates the night before the treatment for apoptosis detection by acridine orange/ ethidium bromide (AO/EB) staining and Hoechst 33258 staining. The cells were exposed to different concentrations of the decoction $(0-1800 \mu \mathrm{g} / \mathrm{ml})$ (test cells) or $1 \%$ DMSO (control cells) respectively for $24 \mathrm{~h}$. After incubation, control and treated cells were harvested by trypsinization, centrifuged and suspended in PBS at a final concentration of $1 \times 10^{5}$ cells $/ \mathrm{ml}$. The cells were fixed by $4 \%$ formaldehyde at room temperature and plated onto glass slides and subjected to apoptosis analysis by acridine orange/ethidium bromide $(\mathrm{AO} / \mathrm{EB})$ staining and Hoechst 33258 staining as described below.

\section{Acridine orange/ethidium bromide (AO/EB) staining}

The AO/EB staining was carried out according to Ribble et al. (2005) [17]. Fluorescent dyes, ethidium bromide $(100 \mu \mathrm{g} / \mathrm{ml})$ and acridine orange $(100 \mu \mathrm{g} / \mathrm{ml})$ were added to the fixed cells and incubated for $10 \mathrm{~min}$ at room temperature in dark. Changes in the nuclei of cells within 15 min. after $\mathrm{AO} / \mathrm{EB}$ staining were observed under a fluorescence microscope (Olympus, BX51TRF, Japan). Morphological criteria were used to evaluate cell injury. Cells containing normal nuclear chromatin exhibit green nuclear staining. Cells containing fragmented nuclear chromatin due to apoptosis exhibit orange to red nuclear staining.

\section{Hoechst 33258 staining}

Characteristic apoptotic morphological changes were assessed by fluorescent microscopy using bis-benzimide (Hoechst 33258) staining. Fixed cells were stained with $200 \mu \mathrm{L}$ of bis-benzimide $(5 \mu \mathrm{g} / \mathrm{mL})$ for $10 \mathrm{~min}$ at room temperature. Then, $10 \mu \mathrm{L}$ of this suspension was placed on a glass slide and covered with a cover slip. The cells were examined using a fluorescence microscope (Olympus BX51TRF, Japan), to determine nuclei fragmentation and chromatin condensation.

\section{DNA fragmentation analysis}

Agarasose gel electrophoresis was used to detect the characteristic ladder pattern of DNA fragmentation as described by Yang et al. (2000) with slight modifications. Cells $\left(2 \times 10^{5}\right.$ cells $\left./ \mathrm{ml}\right)$ exposed to the standardized decoction and positive control (thymoquinone) for 24 and $48 \mathrm{~h}$ were gently scraped and harvested by centrifugation. The cell pellets were incubated for $60 \mathrm{~min}$ at $50^{\circ} \mathrm{C}$ in $100 \mu \mathrm{l}$ lysis buffer (100 mM Tris- $\mathrm{HCl} \mathrm{pH} \mathrm{8,} 100 \mathrm{mM} \mathrm{NaCl}$ and $10 \mathrm{mM}$ EDTA). Proteinase K (10 $\mu \mathrm{l} 20 \mathrm{mg} / \mathrm{ml}$ stock solution) was then added to the lysis mixture and further incubated for $30 \mathrm{~min}$ at $50^{\circ} \mathrm{C}$. RNase $(3 \mu \mathrm{l}$ from $10 \mathrm{mg} / \mathrm{ml}$ stock solution) was then added and the mixture incubated for $2 \mathrm{~h}$ at $50^{\circ} \mathrm{C}$. DNA was extracted with phenol-chloroform-isoamyl alcohol, subjected to $2.0 \%$ of agarose gel electrophoresis, stained with ethidium bromide and visualized under UV light using a gel-doc system (QuantumST4 1100/20 M).

\section{Caspase 3 and caspase 9 activities}

Caspase activities were determined by colorimetric assays using caspase-3, and -9 activation kits (GenScript USA) according to the manufacturer's protocol. The kits are based on spectrophotometric detection of the chromophore $p$ nitroaniline $(p \mathrm{NA})$ after cleavage from the labeled substrate DEVD- $p$ NA. HepG2 cells $\left(2 \times 10^{5}\right.$ cells $\left./ \mathrm{ml}\right)$ were incubated with different concentrations of the decoction $(600 \mu \mathrm{g} / \mathrm{ml}$ and $1200 \mu \mathrm{g} / \mathrm{ml})$ for 24 , and $48 \mathrm{~h}$. Cells were then harvested by trypsinization, washed twice with icecold PBS buffer ( $\mathrm{pH}$ 7.4) and lysed in the supplied lysis buffer containing dithiothreitol (DTT). The supernatant was collected and protein concentration determined using Bradford's reagent. Equal amount of protein $(100 \mu \mathrm{g})$ was incubated with the supplied reaction buffer containing dithiothreitol (DTT) and substrates $(5 \mu \mathrm{l})$ at $37^{\circ} \mathrm{C}$ for $4 \mathrm{~h}$. The caspase activity was determined by measuring changes in absorbance at $405 \mathrm{~nm}$ using the Micro plate reader $\left(E_{\mathrm{x}} 800\right.$ Universal Microplate Reader, BIO-TEK INSTRUMENTS, USA).

\section{Statistical analysis}

Results of RT-PCR were analyzed using Prism 2.01 (Graphpad Prism, San Diego, CA). Two way ANOVA 
was used to detect the effect of concentrations of the decoction and duration of the treatment on the mRNA expression of $\mathrm{Bax}$ and $\mathrm{Bcl}-2$ in HepG2 cells. One way analysis of variance (One way ANOVA) with Dunnett's post test for multiple comparisons was used to find out the concentrations at which the Bax expression was significantly increased while reducing the expression of Bcl-2 in comparison to controls. Effect of the decoction on caspase activities was analysed by using one way ANOVA with Banforroni post test.

\section{Results}

\section{RT-PCR analysis of bax and bcl-2 gene expression in HepG2 cells}

$\mathrm{Bax}$ and $\mathrm{Bcl}-2$ gene expression were normalized to the house keeping GAPDH gene. As evident from Figure 1A, B, Additional file: Figure S1, and Table 2, RT-PCR evaluation of HepG2 cells treated with different concentrations of the decoction $(75 \mu \mathrm{g} / \mathrm{ml}-1200 \mu \mathrm{g} / \mathrm{ml})$ showed in a significant $(P<0.001)$ dose and time dependent increase in Bax mRNA expression along with a significant $(P<0.001)$ decrease in $\mathrm{Bcl}$-2 mRNA expression.

\section{Immunohistochemical analysis and western blot analysis of bax and bcl-2 in HepG2 cells}

As evident from Figure $2 \mathrm{~A}$ and $2 \mathrm{~B}$, immunohistochemical analysis of $\mathrm{Bax}$ and $\mathrm{Bcl}-2$ proteins confirmed the results from RT-PCR analysis of $\mathrm{Bax}$ and $\mathrm{Bcl}-2$ mRNA expression in HepG2 cells. Expression of Bax was increased and Bcl-2 was decreased in treated samples when compared to control samples. In western blot analysis $\mathrm{Bax}$ and $\mathrm{Bcl}-2$ gene expression were normalized to the house keeping $\beta$-actin protein. In support of results obtained by immunohistochemistry and RT-PCR, results of the western blot analysis of Bax and Bcl-2 expression in HepG2 cells $\left(2 \times 10^{5}\right.$ cells/ $\mathrm{ml})$ treated with different concentrations $(0-1200 \mu \mathrm{g} / \mathrm{ml})$ of the standardized decoction (for 12,24 and $48 \mathrm{~h}$ ) also resulted in a time and dose dependent up regulation of Bax along with a down regulation of Bcl-2 (Figure 2C.).

\section{Detection of cell viability, changes related to apoptosis and DNA fragmentation analysis}

Effects of the decoction on cell viability in HepG2 cells and peripheral blood mononuclear cells were compared. As evident from Figure 3A, less anti-proliferative effect on normal PBM cells was observed when compared to the effect of the decoction in HepG2 cells. Characteristic apoptotic morphological changes of HepG2 cells were assessed by the light and fluorescent microcopy (Figure 3B and $3 \mathrm{C}$ ). Fluorescent microscopic examination of HepG2 cells after AO/EB staining (Figure 3C) revealed nuclear condensation, membrane blebbing, nuclear fragmentation and apoptotic bodies (the hallmarks of apoptosis) in cells that had been incubated with the decoction. The number

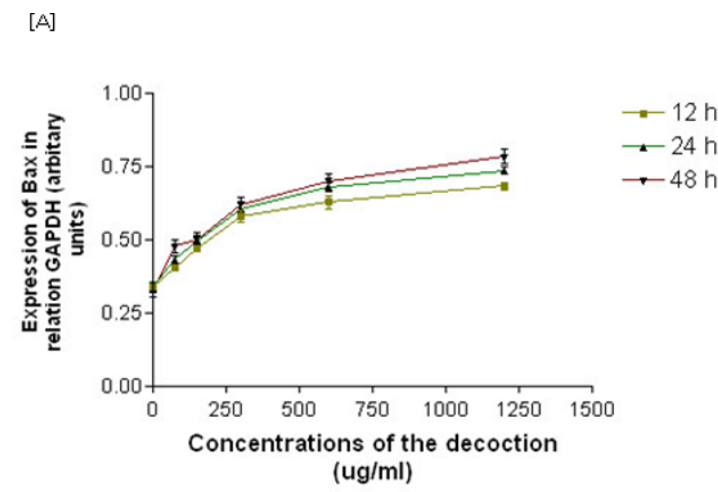

[B]

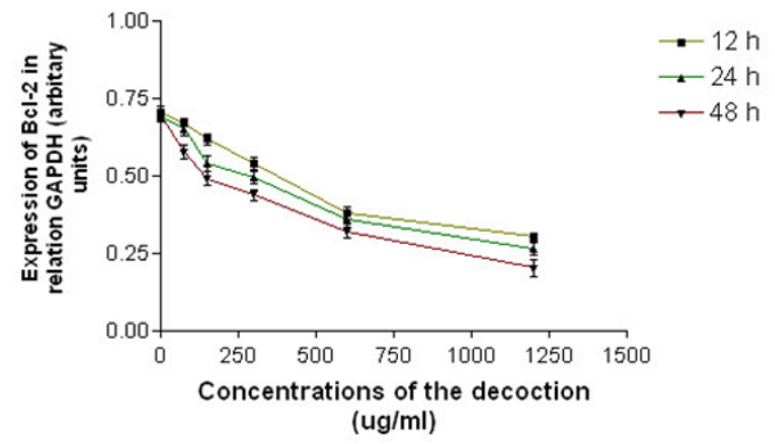

Figure 1 Effects of the decoction on mRNA expression of Bax and Bcl-2 in HepG2 cells treated with the decoction for 12, 24, and $48 \mathbf{~ h}$. Data values are expressed as mean \pm SEM of triplicate determinations. Significant differences were compared to the control at $p^{*}<.01$ by ANOVA with Dunnett's post test for different time points and Two way ANOVA analysis was used to detect the effect of different concentrations of the decoction and duration of the treatment on the mRNA expression of $\mathrm{Bax}$ and $\mathrm{BCl}-2$ in $\mathrm{HepG} 2$ cells.

of cells with orange to red nuclear staining increased with increase in the dose of decoction. The control cells did not exhibit any of the above morphological changes. Chromatin condensation and other apoptotic characters were observed only in the treated cells and not in the control

Table 2 Bax/Bcl-2 ratio of mRNA expression

\begin{tabular}{lccc}
\hline Dose of the decotion & \multicolumn{3}{c}{ Bax/Bcl-2 } \\
\cline { 2 - 4 } & $\mathbf{1 2} \mathbf{h}$ & $\mathbf{2 4} \mathbf{~}$ & $\mathbf{4 8} \mathbf{~}$ \\
\hline Control & 0.484 & 0.489 & 0.468 \\
$75 \mu \mathrm{g} / \mathrm{ml}$ & 0.603 & 0.663 & 0.827 \\
$150 \mu \mathrm{g} / \mathrm{ml}$ & 0.758 & 0.920 & 1.020 \\
$300 \mu \mathrm{g} / \mathrm{ml}$ & 1.074 & 1.220 & 1.410 \\
$600 \mu \mathrm{g} / \mathrm{ml}$ & 1.660 & 1.886 & 2.180 \\
$1200 \mathrm{\mu g} / \mathrm{ml}$ & 2.254 & 2.792 & 3.857 \\
\hline
\end{tabular}

$\mathrm{Bax} / \mathrm{Bcl}-2$ ratio was up regulated in a time and dose dependent manner 


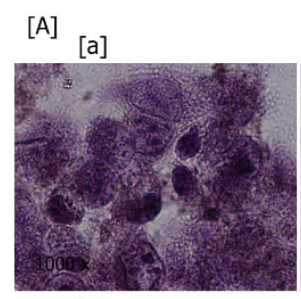

$[c]$

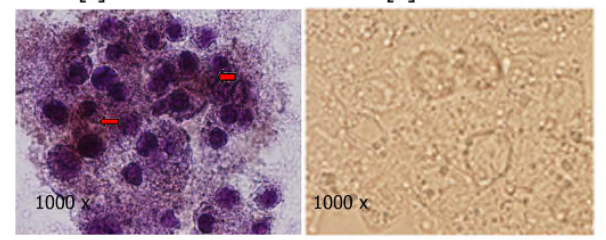

[b]

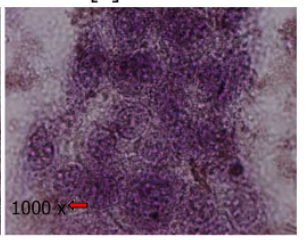

[d]

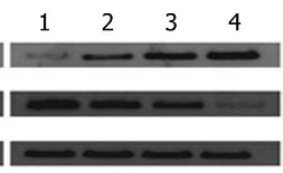

$24 \mathrm{~h}$
[B]

[a]

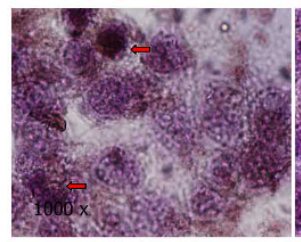

[c]

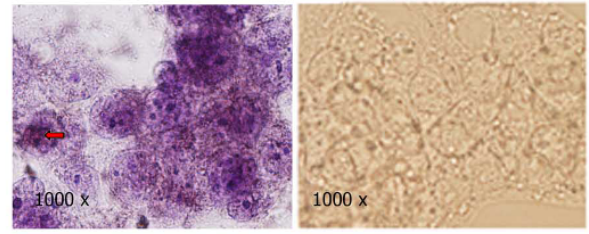

[b]

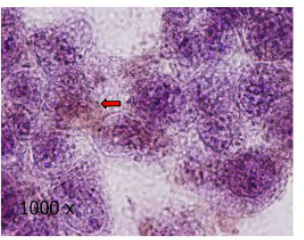

$[\mathrm{d}]$

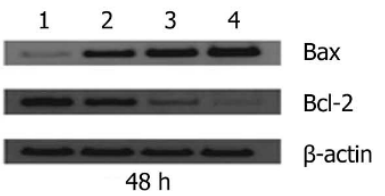

Figure 2 Immunohistochemistry and Western blot analysis. Immunohistochemical analysis analysis of expression of Bax [A] and BCl-2 [B] protein in HepG2 cells (shown by arrows). [a] control (untreated) [b] treated with the decoction $(600 \mu \mathrm{g} / \mathrm{ml})$, [c] treated with the decoction $(1200 \mu \mathrm{g} / \mathrm{ml})$. Section [d] represents the negative control. Hematoxyline was used for counterstaining. [C] Western blot analysis of effects of the decoction on Bax and Bcl-2 expression in HepG2 cells treated with different concentrations (lane 1-control, lane 2-300 $\mu \mathrm{g} / \mathrm{ml}$, lane 3-600 $\mu \mathrm{g} / \mathrm{ml}$, lane 4-1200 $\mathrm{mg} / \mathrm{ml}$ ) of the standardized decoction at (a) $12 \mathrm{~h}$ post incubation, (b) $24 \mathrm{~h}$ post-incubation and (c) $48 \mathrm{~h}$ post incubation was performed as described in the Materials and Methods section. Normalization of bands was performed using $\beta$-actin protein.

cells after staining with Hoechst 33258 (Figure 3D). DNA fragmentation (ladder pattern) characteristic of apoptosis was observed in HepG2 cells $\left(2 \times 10^{5}\right.$ cells $\left./ \mathrm{ml}\right)$ exposed to the standardized decoction for 24 and $48 \mathrm{~h}$. Control cells not exposed to the decoction, showed no evidence of DNA fragmentation (Figure 3E).

\section{Effect of the decoction on the expression of caspase 3 and caspase 9 in HepG2 cells}

As shown in Figure 4 decoction increased the activation of caspase- 3 and caspase-9 in HepG2 cells at concentration of $600 \mu \mathrm{g} / \mathrm{ml}$ and $1200 \mu \mathrm{g} / \mathrm{ml}$ in a significant $(p<0.001)$ time and dose dependent manner.

\section{Discussion}

Previous in vivo and in vitro investigations [1,2] have shown that the decoction, comprised of $N$. sativa seed, $H$. indicus root, and S. glabra, can mediate anti-hepatocarcinogenic effects, without producing any significant toxic side effects. The antihepatocarcinogenic effects of the decoction probably results from an impact of this polyherbal formulation on a broad range of biochemical activities including antioxidant activity [5], anti-inflammatory activity, immunomodulatory activity and modulation of activities of factors involved in cell proliferation and cell cycle arrest $[3,4,6]$. In the study carried out by Thabrew et al., (2005), a flow cytometric analysis of HepG2 cells exposed to the test decoction indicated that this polyherbal formulation also has the potential to induce apoptosis.

Results obtained in the present investigation confirm that apoptosis could indeed be a major mechanism through which the decoction mediates its anti-hepatocarcinogenic effect. Typical features of apoptosis such as chromatin condensation, and nuclear fragmentation were clearly evident in decoction treated HepG2 cells from light microscopic and fluorescent microscopic studies and DNA fragmentation analysis by agarose gel electrophoresis.

Two major pathways (the extrinsic and intrinsic pathways) regulate apoptosis. Both pathways converge to a common pathway involving the activation of a cascade of proteases named caspases that cleave regulatory and structural molecules, culminating in cell death. Caspases are the central components of the apoptotic response and a conserved family of enzymes that irreversibly commit a cell to die. They are cysteine proteases that cleave substrates after specific aspartate residues. The apoptotic caspases which are involved in the regulation and execution of apoptosis are generally divided into two classes: the initiator caspases, which include caspase- $2,-8,-9$ and -10 and the effector caspases, which include caspases-3, -6 and -7 $[18,19]$.

Due to differences in sensitivity, tumours are considered to arise more frequently through the intrinsic pathway than the extrinsic pathway [20]. Transmembrane 
[A]

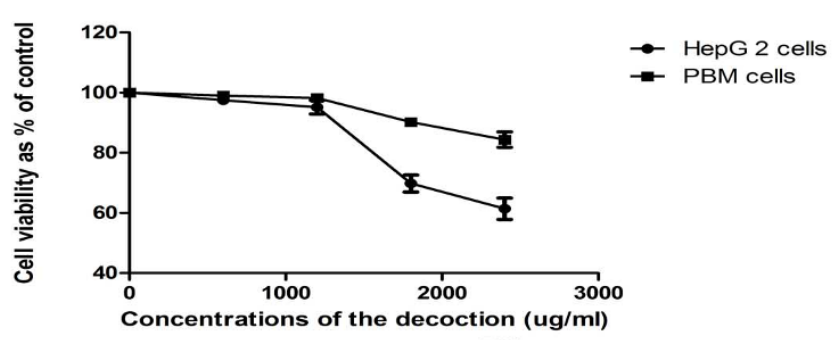

[B] Control

$1200 \mu \mathrm{g} / \mathrm{ml}$

[C]
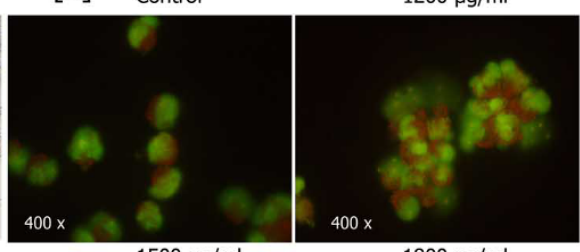

$1800 \mu \mathrm{g} / \mathrm{ml}$

$1500 \mu \mathrm{g} / \mathrm{ml}$

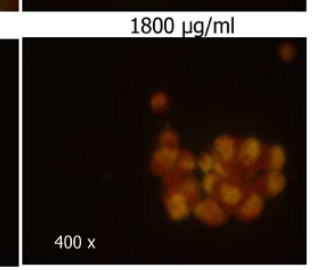

[D]

$100 x$

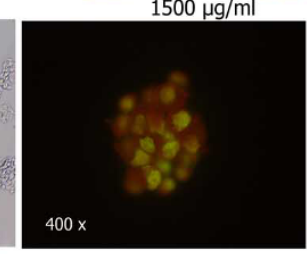

[E]

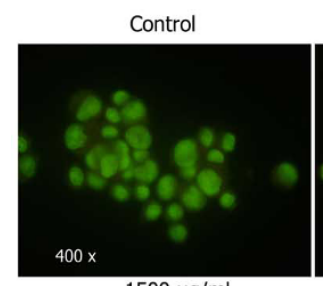

$1200 \mu \mathrm{g} / \mathrm{ml}$
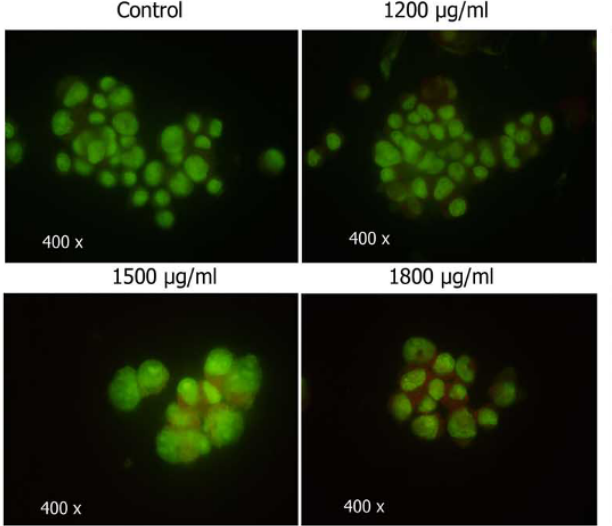

$1800 \mu \mathrm{g} / \mathrm{ml}$

$24 \mathrm{~h}$ post-incubation $48 \mathrm{~h}$ post-incubation

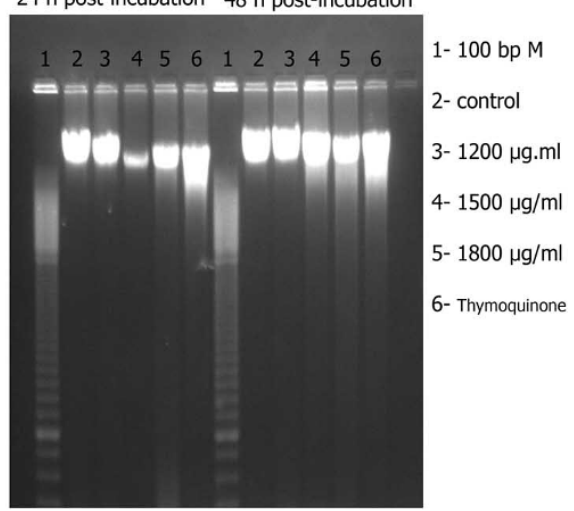

Figure 3 Detection of morphological changes related to apoptosis and DNA fragmentation analysis. Data are representative one of three similar experiments. Induction of decoction on morphological changes, apoptotic bodies formation and DNA fragmentation in HepG2 cells. The cells were treated with indicated dose of decoction for $24 \mathrm{~h}$ and (A) anti-proliferative effect on PBM cells and HepG2 cells (B) photographed by phase contrast microscope. (C) The cells were stained with acridine orange/ethidium bromide and visualized for nuclear morphology and apoptotic bodies under fluorescent microscope using a blue filter (D) The cells were stained with Hoechst 33258 and visualized for nuclear morphology and apoptotic bodies under fluorescent microscope using a blue filter (E) Fragmented DNA was extracted and analyzed on 2\% agarose gel electrophoresis.

receptor -mediated interactions consisting of death receptors (such as Fas), which are members of the tumour necrosis factor (TNF) receptor gene superfamily [21], are reported to be involved in initiation of apoptosis by the extrinsic pathway. In contrast, initiation of apoptosis by the intrinsic pathway involves a diverse array of non-receptor mediated stimuli. These stimuli produce intracellular signals that act directly on targets within the cell and are mitochondrial initiated events [22]. The release of mitochondrial proteins such as cytochrome c, promotes the assembly of a caspase - activating complex (the apoptosome) which in turn can induce activation of caspase- 9 and thereby initiate the caspase cascades participating in apoptosis $[23,24]$. Caspase -9 , the initiator protein, is considered to be an essential element in the intrinsic pathway of apoptosis [23]. Caspase - 3, is reported to be the promoter of apoptosis. Results of the present study demonstrate that the decoction under 
[A]

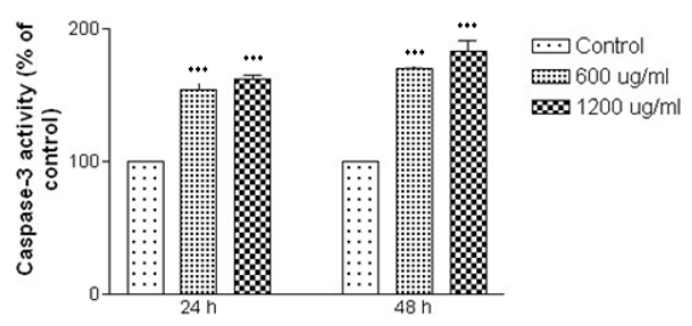

[B]

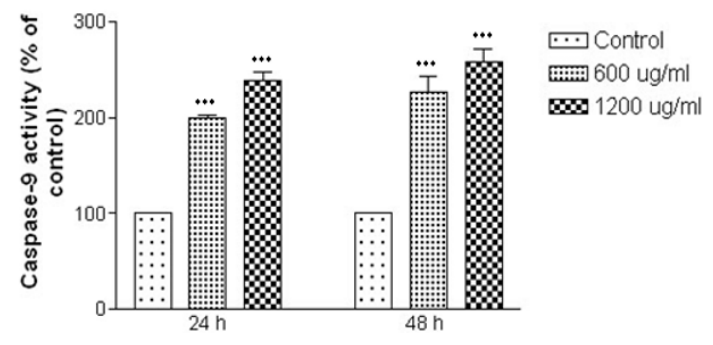

Figure 4 Expression of (A) caspase- 3 and (B) caspase-9 in HepG2 cells treated with the decoction. Results are expressed as mean \pm SEM of triplicate determinations $\left({ }^{* * *} p<0.001\right.$ when compared to the control).

investigation can significantly enhance the activities of both caspase- 3 and caspase- 9 in HepG2 cells in a time and dose dependent manner.

It is well known that apoptosis is tightly regulated by changes in the expression of specific genes. Fas and Bcl2 families of genes are the best known among the factors that modulate cancer related apoptosis. Fas binding to its ligand FasL results in the initiation of active caspase- 8 that can activate caspase- 3 and induce cell apoptosis [25]. The Bcl-2 family of proteins is divided into three subfamilies and pro-apoptotic and anti-apoptotic members have a major role in the regulation of cell death. The anti-apoptotic subfamily comprises of Bcl-2, Bcl-xL, Bclw, Mcl-1, A1 (Bfl-1), and Bcl-B proteins and pro apoptotic subfamily consists of Bax, Bak, Mtd (Bok), and Bcl rambo. Anti-apoptotic members of the Bcl-2 family (among which $\mathrm{Bcl}-2$ is of particular significance), inhibit the release of these apoptogenic factors, whereas proapoptotic members such as Bax, promote its release [26]. Both Bax and Bcl-2 play pivotal roles in caspase activation and the regulation of apoptosis $[27,28]$. In the present study we have demonstrated that in HepG2 cells, in response to the decoction comprising of $N$. sativa seed, $H$. indicus root, and S. glabra, transcription (as demonstrated by RT-PCR) and translation (as demonstrated by immunohistochemistry and western blot analysis) of pro apoptotic Bax gene are significantly enhanced while the transcription and translation of anti apoptotic Bcl-2 gene are significantly reduced.

Overall results obtained indicate that apoptosis is a probable mechanism through which the decoction under test mediates its anti-hepatocarcinogenic effect. To determine the actual percentage of apoptosis a FACS analysis using Annexin- V (FTC conjugated) needs to be conducted. Apoptosis induced by the decoction may be regulated by pro-apoptotic and anti-apoptotic protein members of the Bcl-2 family and is executed through two major caspase pathways, the mitochondria-dependent "intrinsic" cytochrome c/caspase- 9 and caspase-3 pathway.

\section{Conclusions}

In conclusion, the present study demonstrates that the decoction of Nigella sativa seeds, Hemidesmus indicus roots and Smilax glabra rhizomes can induce apoptosis in human hepatocellular carcinoma HepG2 cell, in a dose and time dependent manner through the activation of caspase- 3 and caspase-9, and up regulation of proapoptotic Bax and down regulation of anti-apoptotic Bcl-2 genes which are involved in intrinsic or mitochondrial pathway of apoptosis.

\section{Additional material}

Additional file 1: Figure S1 Effects of the decoction on mRNA expression of Bax and $\mathrm{Bcl}-2$ in HepG2 cells treated with the decoction for 12,24 , and $48 \mathrm{~h}$.

\section{Acknowledgements}

The financial support provided by Sida/secretariat for research cooperation (Formerly SAREC) Grant for Molecular Biology and Biotechnology is gratefully acknowledged.

\section{Author details}

${ }^{1}$ Institute of Biochemistry, Molecular Biology and Biotechnology, University of Colombo, 90, Cumarathunga Munidasa Mawatha, Colombo 3, Sri Lanka.

${ }^{2}$ Department of Biochemistry and Clinical Chemistry, Faculty of Medicine, University of Kelaniya, Thalagolla Road, Ragama, Sri Lanka.

\section{Authors' contributions}

SRS participated in design of the study, preparation of the manuscript and carried out all the experiments and edited the manuscript. IT participated in design of the study and preparation of the manuscript and edited the manuscript. PBG helped for the western blot analysis and literature search. KHT participated in the preparation of the manuscript and edited the manuscript. All authors read and approved the final manuscript.

\section{Competing interests}

The authors declare that they have no competing interests.

Received: 26 October 2011 Accepted: 29 March 2012

Published: 29 March 2012

\section{References}

1. Iddamaldeniya SS, Thabrew I, Wickramasinhe SMDN, Ranathunga N, Thammitiyagoda MG: Protection against diethylnitrosoamine-indused 
hepatocarcinogenesis by an indigenous medicine comprised of Nigella sativa, Hemidesmus indicus, and Smilax glabra. J Carcinog 2003, 2:6-11.

2. Iddamaldeniya SS, Thabrew I, Wickramasinhe SMDN, Ranathunga N, Thammitiyagoda MG: A long term investigation of anti hepatocarcinogenic potential of indigenous medicine comprised of Nigella sativa, Hemidesmus indicus, and Smilax glabra. J Carcinog 2006, 5:11-14.

3. Samarakoon SR, Thabrew I, Galhena PB, De Silva D, Tennekoon KH: A comparison of the cytotoxic potential of standardized aqueous and ethanolic extracts of a polyherbal mixture comprised of Nigella sativa (seeds), Hemidesmus indicus (roots) and Smilax glabra (rhizome). Pharmcog Res 2010, 2:335-342.

4. Thabrew MI, Ragai RM, Morsy Mohammed A, Hughes Robin D: Cytotoxic effects of a decoction of Nigella Sativa, Hemidesmus indicus, and Smilax glabra on human hepatoma Hep G2 cells. Life Sci 2005, 77:1319-1330.

5. Galhena P, Thabrew I, Tammitiyagodage MG, Hanna Rachel VA: Antihepatocarcinogenic Ayurvedic herbal remedy reduces the extent of diethylnitrosamine-induced oxidative stress in rats. Pharmcog Mag 2009, 5:19-27.

6. Samarakoon SR, Thabrew I, Galhena PB, Tennekoon KH: Effects of a standardized preparation of a decoction comprised of Nigella sativa (seeds), Hemidesmus indicus (roots), and Smilax glabra (rhizome) on the expression of p53 and p21 genes in human hepatoma cells (HepG2) and livers of mice with chemically induced hepatocarcinogenesis. Trop J Pharmacut res 2012.

7. Ghobrial IM, Witzig TE, Adjei AA: Targeting Apoptosis Pathways in Cancer Therapy. Cancer J Clin 2005, 55:178-194.

8. Kwon Jl, Hong YH, Kim KH, Han CH, Cho SH, Choi JS, Kim BW: Methanolic extract of Pterocarpus santalinus induces apoptosis in HeLa cells. J Ethnopharmacol 2006, 105:229-234.

9. Brown JM, Attardi LD: The role of apoptosis in cancer development and treatment response. Nat Rev Cancer 2005, 5:231-237.

10. Kroemer G, Galluzzi L, Vandenabeele P, Abrams J, Alnemri ES, Baehrecke EH, Blagosklonny MV, El-Deiry WS, Golstein P, Green DR, Hengartner M, Knight RA, Kumar S, Lipton SA, Malorni W, Nuñez G, Peter ME, Tschopp J, Yuan J, Piacentini M, Zhivotovsky B, Melino G: Classification of cell death: recommendations of the Nomenclature Committee on Cell Death. Cell Death Differ 2009, 16:3-11.

11. Boatwright KM, Salvesen GS: Mechanisms of caspase activation. Curr Opin Cell Biol 2003, 15:725-731.

12. Jin Z, el Deiry WS: Overview of cell death signaling pathways. Cancer Biol Ther 2005, 4:139-163.

13. Fulda S, Debatin KM: Extrinsic verses intrinsic apoptosis pathways in anticancer chemotherapy. Oncogene 2006, 25:4798-4811.

14. Hu YW, Du Liu CM, Zhang J, Wu WQ, Gu ZL: Induction of apoptosis in human hepatocellular carcinoma SMMC-7721 cells in vitro by flavonoides from Astraglas complanatus. J Ethnopharmacol 2009, 123:293-301.

15. Li WY, Chan SW, Guo DJ, Chung MK, Leung TY, Yu PHF: Water extract of Rheum officinale Baill. Induces apoptosis in human lung adenocarcinoma A549 and human Brest cancer MCF-7 cell lines. J Ethnopharmacol 2009, 124:251-256.

16. Bruix J, Sherman M: Management of Hepatocellular Carcinoma. Hepatology 2005, 42:1208-1236.

17. Ribble D, Goldstein NB, Norris DA, Shellman YG: A simple technique for quantifying apoptosis in 96-well plates. BMC Biotechnol 2005, 5:1-7.

18. Abraham MC, Shaham S: Death without caspases, caspases without death. Trends Cell Biol 2004, 14:184-193.

19. Riedl SJ, Shi Y: Molecular mechanisums of caspase regulation during apoptosis. Mol Cell Biol 2004, 5:897-907.

20. Saharma PR, Mondhe DM, Muthiah S, Pal HC, Shahi AK, Saxena AK, Qazi GN: Anti cancer activity of an essential oil from Cymbopogon flexiosus. Chem Biol Interact 2009, 179:160-168.

21. Locksley RM, Killeen N, Lenardo MJ: The TNF and TNF receptor superfamilies: integrating mammalian biology. Cell Death Differ 2001, 104:87-501.

22. Elmore S: Apoptosis: a review of programmed cell death. Toxicol Pathol 2007, 35:495-516.

23. Johnson CR, Jarvis WD: Caspase-9 regulation: and update. Apoptosis 2004, 9:423-427.
24. Sun L, Deng L, Ea CK, Xia ZP, Chen ZJ: The TRAF6 ubiquitin ligase and TAK1 kinase mediate IKK activation by BCL10 and MALT1 in T lymphocytes. Mol Cell 2004, 14:289-301.

25. Nagata S, Goldstein P: The fas death factor. Science 1995, 267:1449-1456.

26. Tsujimoto Y: Bcl-2 Family of Proteins: Life-or-Death Switch in Mitochondria. Biosci Rep 2002, 22:47-58.

27. Adams JM, Cory S: The BCl-2 apoptotic switch in cancer development and therapy. Oncogene 2007, 26:1324-1337.

28. Zhonga Z, Wua D, Huanga J, Liangb H, Pana Z, Zhanga W, Lu H: Progallin A isolated from the acetic ether part of the leaves of Phyllanthus emblica L. induces apoptosis of human hepatocellular carcinoma BEL7404 cells by up-regulation of Bax expression and down-regulation of Bcl-2 expression. J Ethnopharmacol 2011, 133:765-772.

\section{Pre-publication history}

The pre-publication history for this paper can be accessed here: http://www.biomedcentral.com/1472-6882/12/25/prepub

doi:10.1186/1472-6882-12-25

Cite this article as: Samarakoon et al:: Modulation of apoptosis in human hepatocellular carcinoma (HepG2 cells) by a standardized herbal decoction of Nigella sativa seeds, Hemidesmus indicus roots and Smilax glabra rhizomes with anti- hepatocarcinogenic effects. BMC Complementary and Alternative Medicine 2012 12:25.

\section{Submit your next manuscript to BioMed Central and take full advantage of:}

- Convenient online submission

- Thorough peer review

- No space constraints or color figure charges

- Immediate publication on acceptance

- Inclusion in PubMed, CAS, Scopus and Google Scholar

- Research which is freely available for redistribution

Submit your manuscript at www.biomedcentral.com/submit
Ciomed Central 